\title{
Prevalence and Characteristics of Insomnia Problems Among Adults in Central Istria
}

\author{
Tina Zavidić1,2, Valerija Bralić Lang ${ }^{3,4}$ \\ ${ }^{1}$ Istrian Health Center, Pazin, Croatia, ${ }^{2}$ Department of Family Medicine, University of \\ Rijeka, Faculty of Medicine, Rijeka, Croatia, ${ }^{3}$ Family Physician Office, Zagreb, Croatia, \\ ${ }^{4}$ Department of Family Medicine, University of Zagreb, Faculty of Medicine, Zagreb, \\ Croatia
}

\begin{abstract}
Aim: We sought to examine the frequency and characteristics of insomnia among adults in central Istria, as well as to analyse sociodemographic characteristics and explore whether there is an association between symptoms of insomnia and sociodemographic parameters. Methods: This research included 685 participants that visited family medicine offices (FMOs) in Central Istria from September till December 2016. Mean age of the sample was $52.73 \pm 17.93$ years. Participants were randomly selected and interviewed and all gave their informed consent. Participants with sleep disturbances and insomnia lasting one year prior to study enrolment were assessed using the questionnaire designed for the study; along with gathering of sociodemographic data. Results: More than half of the participants had insomnia, $30 \%$ of them each night or several times a week, mostly older participants and women. Regardless of the frequency of insomnia symptoms, all participants reported great impairment in all areas of daytime functioning. The most frequent incidence of insomnia was associated with more frequent sleep apnoea and less frequent bruxism. Frequent night awakenings and restless legs syndrome were not related to a greater incidence of insomnia. Conclusion: Insomnia is a common problem among patients treated in primary care. Family physicians are therefore in an ideal position to identify, evaluate and treat insomnia. The high prevalence of insomnia highlights the need for a more adequate recognition and treatment of this psychiatric illness.
\end{abstract}

Key words: insomnia; sleep problems; prevalence; family medicine

Copyright (C) 2021 KBCSM, Zagreb

e-mail: apr.kbcsm@gmail.com•www.http://apr.kbcsm.hr

\section{Introduction}

Insomnia disorder is a condition characterized by both nocturnal and diurnal symptoms. It involves a predominant complaint of dissatisfaction with sleep quality or duration and is accompanied by difficulties in initiating sleep at bedtime, frequent or prolonged awakenings,

\section{Correspondence to:}

Tina Zavidić

Istrian Health Center, Pazin

J. Dobrile 1,52000 Pazin, Croatia

Phone: +385 991970840

E-mail: tina.zavidic@gmail.com or early-morning awakening with an inability to return to sleep $[1,2]$. These difficulties occur despite adequate opportunity for sleep and are associated with impairment of daytime functioning, including fatigue, decreased energy, mood disturbances and reduced cognitive functions, such as impaired attention, concentration and memory [3].

The incidence of insomnia varies between the examined population of different countries and ranges from $6 \%$ to $76.3 \%$, depending on the methods of data collection, different 
definitions of insomnia and the period of the research $[4,5]$. A survey conducted in five family medicine offices in North Carolina on adult patients showed that more than one third of patients had insomnia [6]. According to a survey conducted in the adult population of Brazil, 63\% of patients had at least one sleep disorder while $35 \%$ had insomnia more than three times a week [7] and in Sweden it has been shown that a third of the population had symptoms of insomnia at least four times a week [8]. Gender and age are the most prominent demographic risk factors for developing insomnia, with a higher prevalence in women and elderly $[9,10]$. Insomnia has several subtypes due to the appearance of the symptoms. According to epidemiological studies worldwide, difficulty maintaining sleep and difficulty initiating sleep are the most common symptoms. In practice, overlapping symptoms of these subtypes are mostly present and they represent a large problem and an even greater challenge in treatment for every physician. Insomnia is very common in the general population, but is most often interpreted as a symptom of another illness or mental condition.

Family physicians are consulted more frequently than other health professionals for sleep problems and patients typically prefer non-pharmacological treatment strategies. Patients rarely have insomnia as a separate diagnosis in their health records and the reasons for that vary $[11,12]$. Sometimes patients themselves do not pay attention to insomnia and they do not even mention it to their doctor as they simply attribute insomnia as a symptom of some of their already known illnesses. Due to its chronic nature, insomnia leads to substantial impairment in emotional, mental health and quality of life [13]. The daytime consequences include increased risk of accidents, decreased work productivity, concentration and daily performance and therefore family physicians are at an ideal position to identify, evaluate and treat it $[14,15]$.
Almost none of the studies about sleep problems or insomnia in particular have been done in family medicine offices (FMOs), which are usually the first contact with the diagnosis and treatment of many different conditions. Family medicine offices are neglected places in which it is possible to get the most accurate data from patients and their doctor. The aim of this study was to examine the prevalence and characteristics of insomnia problems among adults treated in selected FMO in Central Istria. We also aimed to find whether there is a connection between insomnia symptoms and some sociodemographic characteristics of patients.

\section{Subjects and Methods}

\section{Study design, setting and participants}

This was a multicentre and cross-sectional study that took place from September till December 2016. It was conducted in three FMOs in Central Istria, two in the town of Pazin and one in the neighbouring municipality of Lupoglav. Selected FMO account for one third of all FMOs in Central Istria and care for $62.8 \%$ of the overall adult population. A convenience sample of patients was taken. In each of the three participating FMOs (which care for a total of 4994 adults), 14\% of adult patients were randomly selected. The random number generator created a list of numbers (respondents) from a numbered list of patients for each individual FMO. The main criterion for inclusion of participants in this study was at least 18 years of age, while exclusion criteria were comorbid somatic illnesses with a life expectancy of less than six months. Of 710 patients participating in the survey, 685 (96.5\%) responded (Figure 1.). The sample represents $13.7 \%$ of adults in three FMOs and $8.6 \%$ of the total adult population in Pazin and Lupoglav.

The survey was conducted using a questionnaire prepared specifically for the need of this research. Every patient was interviewed by the head investigator of this study. Before the study began, 


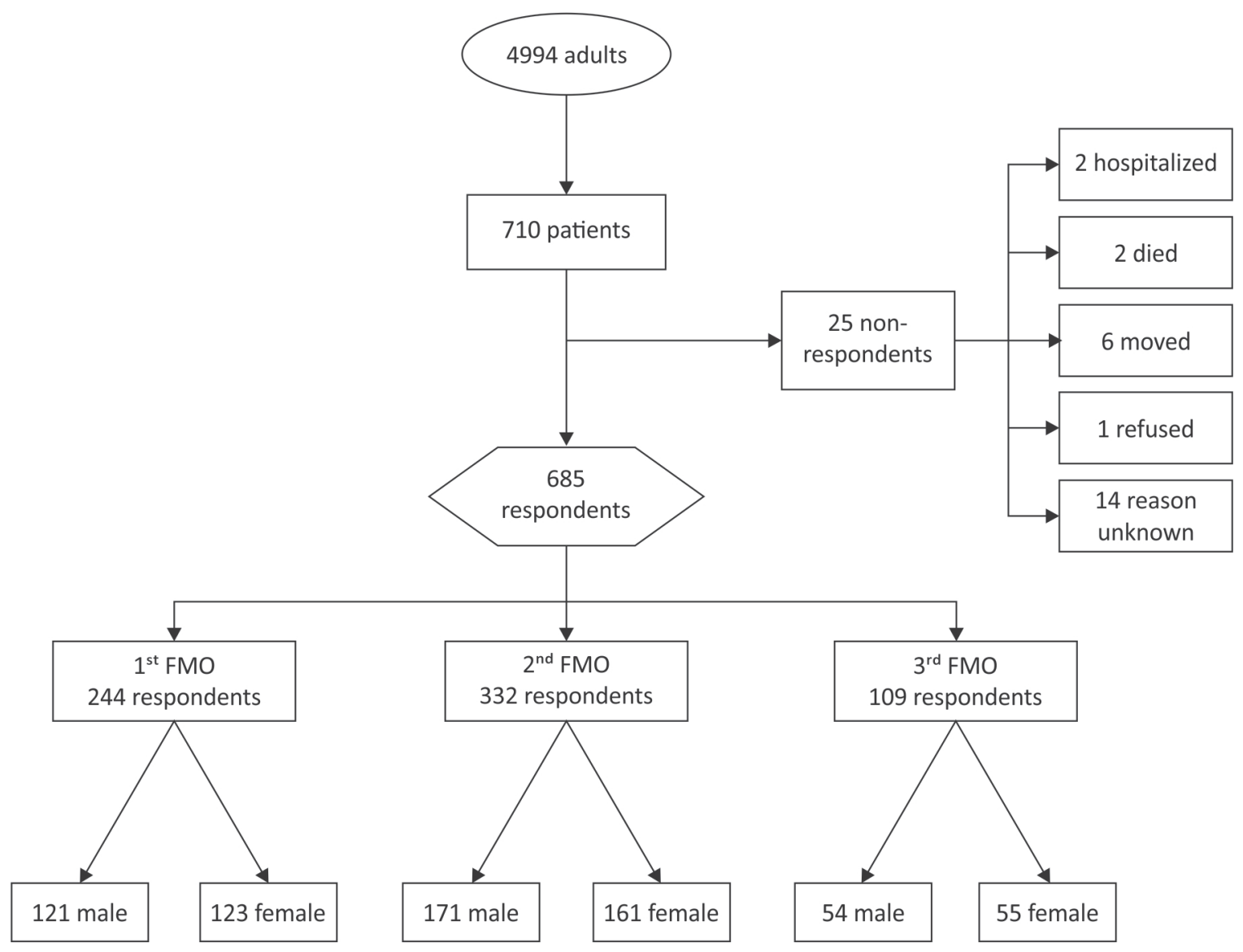

FMO - family medicine office

Figure 1. Participant flowchart for this survey

the purpose of the examination, voluntary participation and the anonymity were explained in detail. If they agreed voluntarily to participate, the patients signed an informed consent and then verbally answered questions. The questions were closed type, with two to five responses. The first section of the questionnaire referred to general data - age, gender, education and working status. The second part of the questionnaire referred to information about insomnia during the previous year where patients responded to questions about the duration and frequency of insomnia, the necessity for sleep medications, average duration of sleep, frequency of waking up during the night and whether insomnia disturbed their everyday life. The third section of the questionnaire was related to types of insomnia, i.e. patients responded to questions about difficulty initiating sleep, difficulty maintaining sleep or early morning awakening.

\section{Statistical analysis}

Continuous variables are shown as mean values (standard deviation) and categorical variables (nominal and dichotomous) as absolute (relative) 
frequencies. The differences in the continuous variables between the groups were tested by oneway variance analysis (ANOVA) and the category variables $\chi 2$-test. Variables that proved to be significant in univariate comparisons were included in multinational logistic regression. The level of significance was determined as $\alpha<0,05$. Bonferroni correction of the level of significance was used for multiple comparisons and all the tests were two-sided. SPSS, version 17.0 (SPSS, Chicago, IL, USA) was used for statistical analysis.

\section{Ethical approval}

This study was conducted according to the guidelines for human studies determined by the Ethical Committee of School of Medicine, University of Zagreb and was approved by the Ethical Committee of Istria Health Centre (Pula, 17 $7^{\text {th }}$ October 2014, approval No. 4378/2014.).

\section{Results}

The study included 685 patients, 346 (51\%) were men. The sociodemographic characteristics of the sample are given in Table 1. Most patients were aged $46-64$ years $(n=245)$ and 31 - 45 years $(n=157)$, respectively. More than one third of the patients in this study has insomnia problems, some of them several times a week $(17.5 \%)$ and some every night (13.0\%). Also, $21.5 \%$ of the patients have insomnia problems several times a month. According to a time interval in which they occurred most commonly represented were difficulty initiating sleep (26.1\%), early morning awakening $(23.1 \%)$ and difficulties maintaining sleep $(16.1 \%)$.

Patients who had insomnia problems every night compared to patients without insomnia problems, were older $(65.1 \pm 14.1)$ and more often women (70\%). Patients who had insomnia problems several times a week were younger $(59.2 \pm 15.3)$ and more commonly female $(60 \%)$ unlike those suffering from insomnia problems each night (Table 1).
Furthermore, more frequent incidences of insomnia problems were associated with more frequent apnoea and less frequent bruxism which is an interesting result. Frequent awakening during the night, restless legs and some symptoms of apnoea (breathlessness, snoring) were not related to a greater incidence of insomnia problems (Table 2).

Patients with more frequent insomnia symptoms slept less hours and often woke up five or more times during the night, while those who had no insomnia problems fell asleep more quickly and easily and never had problems with insomnia (Table 3).

Post hoc analysis shows that whether the problems of insomnia were present every evening or several times a week, they equally disturbed the everyday life of the respondent, including insomnia problems which occurred only several times a month.

\section{Discussion}

The results of the study show that $52 \%$ of patients had insomnia problems with 30.5\% of patients having insomnia problems every night or several times a week. According to the time interval in which sleep problems occurred, they were represented by difficulty initiating sleep (26.1\%), difficulties maintaining sleep $(16.1 \%)$ and early morning awakening (23.1\%). Patients who had insomnia problems were mostly older and women.

This study included a sample of more than $10 \%$ of patients from Central Istria and showed a large prevalence of insomnia problems among the patients. Studies have been conducted around the world and similar results have been obtained in most of them. As in this study, numerous studies have shown that women and older patients have a greater prevalence of sleep problems than younger patients [16,17]. A potential reason for the sex difference in the prevalence of insomnia is gonadal steroid effects, as the rise in insom- 


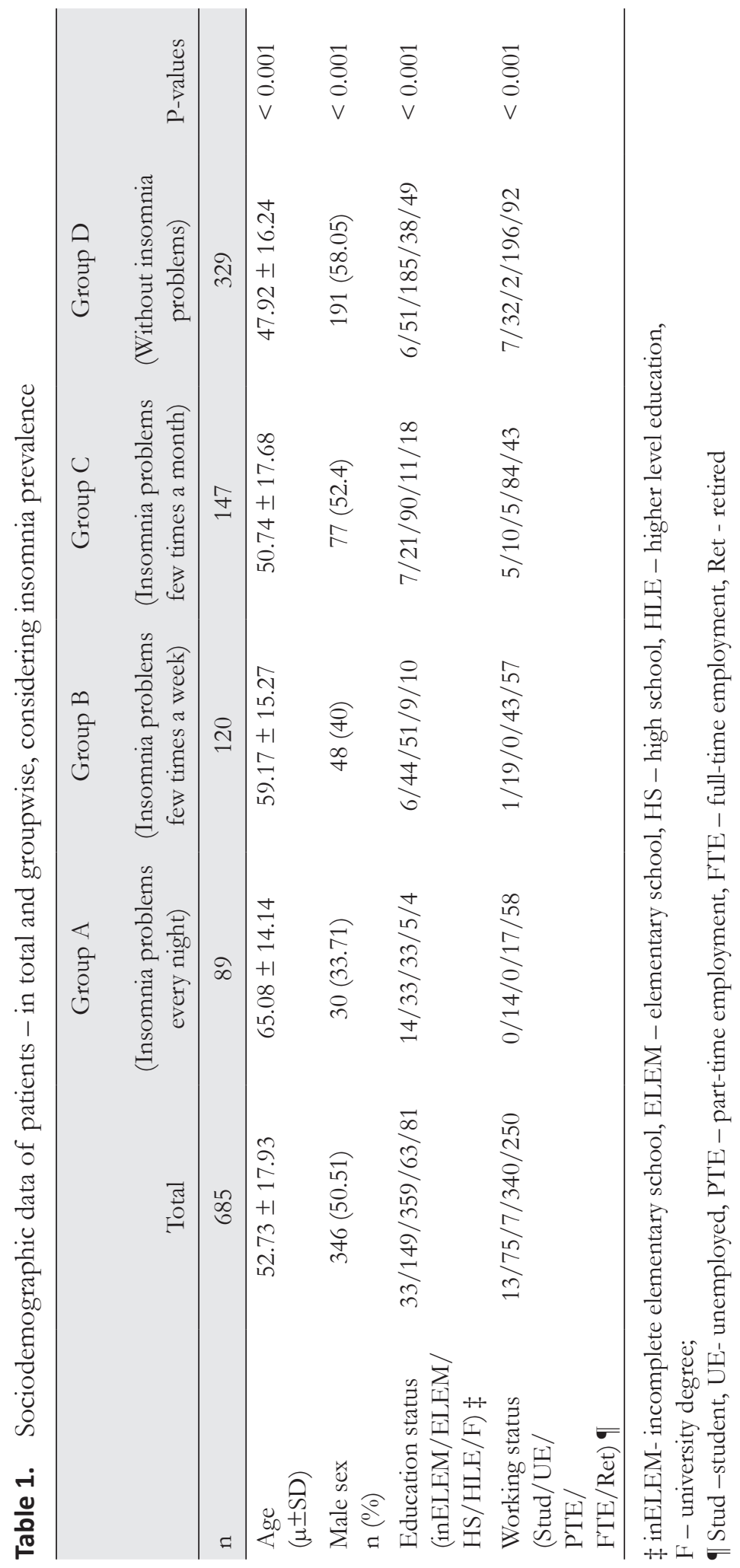


Table 2. Symptoms of insomnia problems regarding their frequency during the period of one year prior to the study

\begin{tabular}{|c|c|c|c|c|c|}
\hline & $\begin{array}{l}\text { Group A } \\
\text { (insomnia } \\
\text { problems } \\
\text { every night) }\end{array}$ & $\begin{array}{c}\text { Group B } \\
\text { (insomnia } \\
\text { problems few } \\
\text { times a week) }\end{array}$ & $\begin{array}{c}\text { Group C } \\
\text { (insomnia } \\
\text { problems few } \\
\text { times } \\
\text { a month) }\end{array}$ & $\begin{array}{l}\text { Group D } \\
\text { (without } \\
\text { insomnia } \\
\text { problems) }\end{array}$ & P-values \\
\hline Difficulty initiating sleep n (\%) & $51(57.30)$ & $68(56.67)$ & $37(25.17)$ & $23(6.99)$ & $<0.001^{*}$ \\
\hline Difficulty maintaining sleep n (\%) & $44(49.44)$ & $42(35)$ & $11(7.48)$ & $13(3.95)$ & $<0.001^{\dagger}$ \\
\hline Frequent awakening n (\%) & $2(2.25)$ & $4(3.33)$ & $4(2.72)$ & $2(0.61)$ & 0.159 \\
\hline Sleep apnea n $(\%)$ & $6(6.74)$ & $3(2.5)$ & $2(1.36)$ & 0 & $<0.001^{\ddagger}$ \\
\hline $\begin{array}{l}\text { Breathlessness/gasp for breath } \\
\text { during sleep n ( } \%)\end{array}$ & 0 & 0 & 0 & $3(0.91)$ & 0.353 \\
\hline Moonwalking $\mathrm{n}(\%)$ & $22(24.72)$ & $26(21.67)$ & $22(14.97)$ & $18(5.47)$ & $<0.001^{\S}$ \\
\hline Restless legs n (\%) & $38(42.7)$ & $44(36.67)$ & $63(42.86)$ & $112(34.04)$ & 0.209 \\
\hline Snoring n $(\%)$ & $5(5.62)$ & $6(5)$ & $7(4.76)$ & $8(2.43)$ & 0.342 \\
\hline Bruxism n $(\%)$ & $20(22.47)$ & $38(31.67)$ & $65(44.22)$ & $196(59.57)$ & $<0.001^{\natural}$ \\
\hline Early morning awakening $\mathrm{n}(\%)$ & $46(51.69)$ & $52(43.33)$ & $29(19.73)$ & $31(9.42)$ & $<0.001^{\#}$ \\
\hline
\end{tabular}

*test $\chi 2$ results: post hoc testing all differences are statistically significant, except $\mathrm{A}$ versus $\mathrm{B}$; $†$ test $\chi 2$ results: by post hoc testing, all differences are statistically significant, except $A$ versus $B$ and $C$ versus $D ; \ddagger$ test $\chi 2$ results: post hoc testing does not have statistically significant differences; Results of $\chi^{2}$ test: post hoc testing is statistically significant except for A versus D, B versus D and C opposite D; T The results of the $\chi^{2}$ test: by post hoc testing all differences are statistically significant except A versus B and B versus $C$; \# test $\chi^{2}$ results: post hoc testing all differences are statistically significant except for A versus B

nia prevalence in women compared with men begins at puberty and increases during and after menopause $[7,18]$. One of these studies was conducted in Sweden, where it has shown an increase in incidence of insomnia among women, older population and unemployed persons [16]. Research in rural and urban areas of Beijing showed a lower incidence of insomnia, approx. 9\%, but with high association of insomnia with older age, female sex, serious health status and mental disorders [19]. In a Finnish survey, there was a $37 \%$ incidence of insomnia, but there were no statistically significant differences between males and females [20].
The increasing age of patients also increases the incidence of insomnia problems. It is assumed that an increase in age increases the incidence of somatic symptoms, various $\mathrm{CO}^{-}$ morbidities, mental illnesses and consequently the frequency of insomnia problems. The only study which differs is the Finnish study where a greater prevalence of insomnia was indicated in younger patients [20].

Post hoc analysis showed that insomnia problems, regardless of their frequency, equally disturb the everyday life of the respondent and are associated with impairment of daytime functioning, including fatigue, decreased energy, mood disturbances and reduced cogni- 


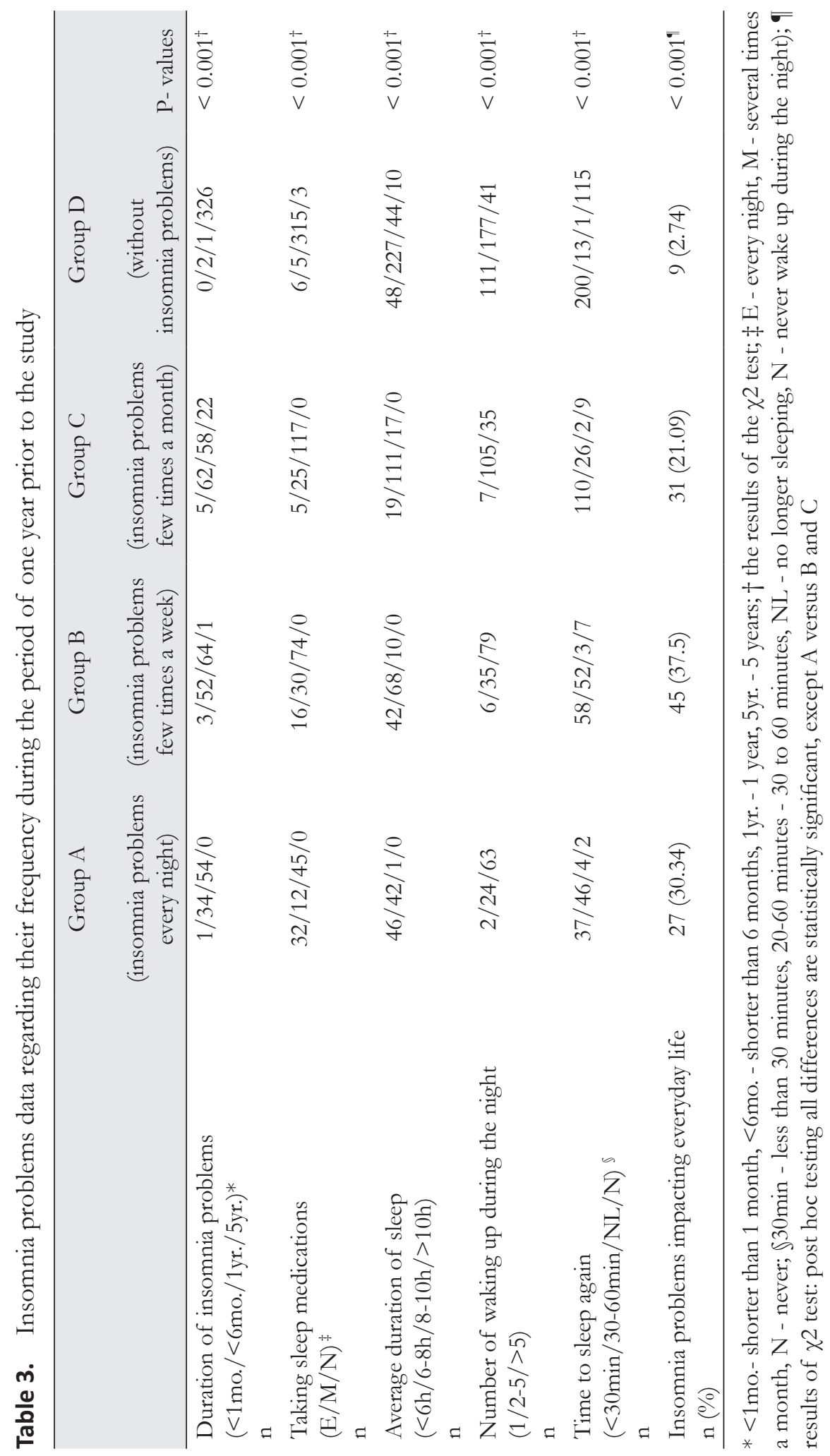


tive functions, such as impaired attention, concentration and memory [3]. This data proves that insomnia affects the quality of life of an individual almost like some other noncommunicable chronic illness. There are numerous studies which show that sleep disorders negatively affect the quality of life and pose a risk for many inflammatory and chronic noncommunicable diseases [21-24].

The most common symptoms in patients with insomnia were difficulties initiating sleep (56 - 57\%), followed by difficulties of early awakening (43 - 52\%) and difficulties maintaining sleep (25 - 49\%). Similar data obtained in the Swedish study showed that the odds ratio for difficulty initiating sleep is 19.91, for problems related to early morning awakening 6.03 and difficulties maintaining sleep 5.97 [8]. Different results were obtained by a Turkish study where $42.2 \%$ of patients had difficulties initiating sleep, $24.6 \%$ had a problem with sleep continuity and $24.6 \%$ of patients had problems with early awakening [13]. In the study conducted in Beijing the frequency of difficulty initiating sleep was $7 \%$, difficulty maintaining sleep $8 \%$ and early awakening $4.9 \%$. In addition, there was no statistically significant difference between the data obtained in urban and rural areas of Beijing, although the frequency of insomnia in all three subgroups of insomnia in Beijing's urban areas was lower [19].

Data from this study shows that more frequent incidence of insomnia problems is associated with more frequent apnoea symptoms, such as heteroanamnestic reported episodes of cessation of breathing, gasping for air during sleep, awakening with a dry mouth or load snoring. All this symptoms can indicate a potentially serious problem, and can be related to the so called OSA (Obstructive Sleep Apnoea) syndrome, which includes episodes of partial and/or complete closing of the upper respiratory tract during sleep resulting in a discontinuation of breathing for more than ten sec- onds. According to research, about $50-55 \%$ of patients with undergoing treatment for sleep apnoea had insomnia [25].

The diagnosis "snoring" was made by the International Classification of Sleep Disorders (ICSD-3) following criteria, based on patients reported anamnesis or heteroanamnesis of respiration-dependent, generally inspiratory, acoustic phenomena during sleep, not caused by another sleep-related respiratory disorder [2]. In this study, snoring is represented only by $3.8 \%$, while in the Brazilian's survey snoring is among the most common problems during sleep $(29 \%)$ especially in patients older than 45 [7]. An even higher percentage (37\%) was recorded in a survey conducted in North Carolina, where $13 \%$ of patients also had apnoea [6].

According to participants who reported frequent tooth-grinding during sleep, bruxism is based on self-report only and it was present in this study in $46.7 \%$ of patients. Data also shows an association of more frequent insomnia with less frequent bruxism. In the survey conducted in Finland among the staff working in shifts, bruxism was present in 10.6\% of patients and was associated with insomnia symptoms (except early morning awakening) and insufficient sleep [26].

Symptoms of restless legs syndrome, which is recorded in $16.3 \%$ of patients in this study, is more common than in other studies around the world. It is diagnosed based on an urge to move the legs not solely accounted for as symptoms primary to another medical or a behavioural condition (such as leg cramps, myalgia, arthritis, venous stasis, positional discomfort etc.). There are data on the frequency of $4 \%$ to $11 \%$ in adult patients and it is considered that it increases with age [27]. In $85 \%$ of patients with restless legs syndrome, there are difficulties initiating sleep and sometimes even awakening due to uncomfortable sensations in the legs [28]. One third of patients in North Carolina had restless legs. This high percent- 
age is explained by the possible delayed diagnosis of this frequent problem [6].

The limitation of this research, as well as the others that have been conducted so far, is the absence of a single questionnaire and a single criterion for insomnia. The questionnaire should include all possible symptoms associated with insomnia and should also eliminate the misconceptions attributed to other mental and physical illnesses. The problem lies in the number of insomnia classifications so the results may be interpreted in various versions which prevent us from accurately assessing the frequency of insomnia problems in the population, thus making it difficult for doctors to diagnose and treat patients.

The strength of this study is primarily in a sample size which represents nearly 9\% of the total adult population in Central Istria. The questions were closed type so it is easy to compare with other responders or questionnaires. This type of research can be used to create new research questions.

Further validation of practice guidelines and foster their use in various clinical settings,

\section{References}

1. American Psychiatric Association. Diagnostic and Statistical Manual of Mental Disorders, $5^{\text {th }}$ ed.: DSM-5. American Psychiatric Association, 2013.

2. American Academy of Sleep Medicine. International classification of Sleep Disorders, $3^{\text {rd }}$ ed. Darien, IL: American Academy of Sleep Medicine, 2014.

3. Morin CM, Drake CL, Harvey AG, Krystal AD, Manber $\mathrm{R}$, Riemann D, Spiegelhalder Ket al. Insomnia disorder. Nat Rev Dis Primers. 2015;1:15026.

4. Ohayon MM, Lemoine P. A connection between insomnia and psychiatric disorders in the French general population. Enchephale. 2002;28:420-8.

5. Rocha FL, Guerra HL, Lima-Costa MF. Prevalence of insomnia and associated sociodemographic factors in especially family medicine offices, and involving a higher number of participants from different part of our country for the future research is necessary. Recommendations are based on reducing unrecognized and untreated insomnia problems and consequently negative impairment of daytime functioning.

Insomnia is a common problem among patients treated in primary care and a variable risk factor which can and should be acted upon. Family physicians have a great role in this matter. They are in an ideal position to identify, evaluate and treat insomnia. The high prevalence of insomnia highlights the need for more education and researches and commits health care to recognize and treat this problem.

\section{Acknowledgements}

None.

\section{Conflict of Interest}

None to declare. a Brazilian community: the Bambui study. Sleep Med. 2002;3:121-6.

6. Alattar M, Harrington JJ, Mitchell CM, Sloane P. Sleep problems in primary care: a North Carolina Family Practice Research Network (NC-FP-RN) study. J Am Board Fam Med. 2007;20:365-74.

7. Bittencourt LRA, Santos-Silva R, Taddei JA, Andersen ML, de Mello MT, Tufik S. Sleep complaints in the adult Brazilian population: a national survey based on screening questions. J Clin Sleep Med. 2009;5:459-63.

8. Ohayon MM, Bader G. Prevalence and correlates of insomnia in the Swedish population aged 19-75 years. Sleep Med. 2010;11:980-6.

9. Ohayon MM. Epidemiology of insomnia: what we know and what we still need to learn. Sleep Med Rev. 2002;6:97-111. 
10. Gu D, Sautter J, Pipkin R, Zeng Y. Sociodemographic and health correlates of sleep quality and duration among very old Chinese. Sleep. 2010;33:601-10.

11. Morin CM, LeBlanc M, Daley M, Gregoire JP, Mérette C. Epidemiology of insomnia: prevalence, self-help treatments, consultations, and determinants of helpseeking behaviours. Sleep Med. 2006;7:123-30.

12. Morin CM, Gaulier B, Barry T, Kowatch RA. Patients' acceptance of psychological and pharmacological therapies for insomnia. Sleep. 1992;15:302-5.

13. Benbir G, Demir AU, Aksu M, Ardic S, Firat H, ${ }^{\text {Itil }}$ O., et al. Prevalence of insomnia and its clinical correlates in a general population in Turkey. Psychiatry Clin Neurosci. 2015;69:543-52.

14. Léger D, Guilleminault C, Bader G, Levy E, Paillard M. Medical and socio-professional impact of insomnia. Sleep. 2002;25:625-9.

15. Roth T. Prevalence, associated risks, and treatment patterns of insomnia. J Clin Psychiatry. 2005;66:10-43.

16. Sandlund C, Westman J, Hetta J. Factors associated with self-reported need for treatment of sleeping difficulties: a survey of the general Swedish population. Sleep Med. 2016;22:65-74.

17. Zhang B, Wing YK. Sex differences in insomnia: a metaanalysis. Sleep. 2006;29:85-93.

18. Johnson EO, Roth T, Schultz L, Breslau N. Epidemiology of DSM-IV insomnia in adolescence: lifetime prevalence, chronicity, and an emergent gender difference. Pediatrics. 2006;117:e247:e256.

19. Xiang Y'T, Ma X, Cai ZJ, Li SR, Xiang YO, Guo HL, et al. The prevalence of insomnia, its sociodemographic and clinical correlates, and treatment in rural and urban regions of Beijing, China: a general population-based survey. Sleep. 2008;31:1655-62.
20. Ohayon MM, Partinen M. Insomnia and global sleep dissatisfaction in Finland. J Sleep Res. 2002;11:339-46.

21. Dew MA, Hoch CC, Buysse DJ, Monk TH, Begley AE, Houck PR, et al. Healthy older adults' sleep predicts allcause mortality at 4 to 19 years of follow-up. Psychosom Med. 2003;65:63-73.

22. Kripke DF, Garfinkel L, Wingard DL, Klauber MR, Marler MR. Mortality associated with sleep duration and insomnia. Arch Gen Psychiatry. 2002;59:131-6.

23. Mallon L, Broman JE, Hetta J. Sleep complaints predict coronary artery disease mortality in males: a 12-year follow-up study of a middle-aged Swedish population. J Intern Med. 2002;251:207-16.

24. Vgontzas AN, Fernandez-Mendoza J, Liao D, Bixler EO. Insomnia with objective short sleep duration: the most biologically severe phenotype of the disorder. Sleep Med Rev. 2013;17:241-54.

25. Krell SB, Kapur VK. Insomnia complaints in patients evaluated for obstructive sleep apnea. Sleep Breath. 2005;9:104-10.

26. Ahlberg K, Jahkola A, Savolainen A, Könönen M, Partinen M, Hublin C, et al. Associations of reported bruxism with insomnia and insufficient sleep symptoms among media personnel with or without irregular shift work. Head Face Med. 2008;4:4.

27. Hornyak M, Feige B, Riemann D, Voderholzer U. Periodic leg movements in sleep and periodic limb movement disorder: prevalence, clinical significance and treatment. Sleep Med Rev. 2006;10:169-77.

28. Montplaisir J, Allen RP, Walters AS, Ferini-Strambi L. Restless legs syndrome and periodic limb movements during sleep. In: Kryger M, Roth T, Dement WC, ed(s). Principles and Practice of Sleep Medicine, 4th ed. New York, USA: Saunders; 2005. p. 839-52.

\section{Prevalencija i značajke nesanice među odraslima u središnjoj Istri}

Sažetak - Cilj: Istražiti učestalost i obilježja problema spavanja među odraslim ispitanicima centralne Istre, analizirati sociodemografske karakteristike ispitanika i ispitati postoji li povezanost između pojedinih simptoma nesanice i sociodemografskih karakteristika ispitanika. Metode: 685 ispitanika prosječne dobi $52.73 \pm 17.93$ ( \pm standardna devijacija), posjetilo je ordinacije obiteljske medicine u centralnoj Istri, u razdoblju od rujna do prosinca 2016. Ukupno je 14\% odraslih ispitanika nasumično izabrano i anketirano. Svi ispitanici su potpisali informativni pristanak. Ispitivani su anketnim upitnikom koji se odnosio na razdoblje od godine dana prije istraživanja i napravljen je posebno za ovo istraživanje; također su prikupljeni sociodemografski podaci ispitanika. Rezultati: Više od polovice ispitanika imalo je probleme spavanja, no $30 \%$ ispitanika imalo je probleme spavanja svaku noć ili nekoliko puta tjedno, a najčešće su to bili stariji ispitanici i žene. Problemi spavanja, neovisno o učestalosti, jednako su ometali svakodnevicu ispitanika. Češća pojavnost problema spavanja bila je povezana s češćom apnejom u snu i manjom učestalosti škrgutanja zubima. Češća buđenja tijekom noći i nemirnost nogu 
kod ispitanika nisu bili povezani s većom učestalošću problema spavanja. Zaključak: Problemi spavanja su učestali među bolesnicima liječenim u primarnoj zdravstvenoj zaštiti stoga su liječnici obiteljske medicine idealno pozicionirani za njihovo pravodobno prepoznavanje, evaluaciju i liječenje. Velika učestalost problema spavanja naglašava potrebu za daljnjim edukacijama i istraživanjima, a zdravstvenu skrb obvezuje na rano prepoznavanje i liječenje ovih problema.

Ključne riječi: nesanica; problemi spavanja; učestalost; obiteljska medicina 
